\title{
Green Maintenance Approach: Low Carbon Repair Appraisal on St Paul's Church, Melaka, Malaysia
}

\author{
Brit Anak Kayan, Noor Suzaini Mohamed Zaid and Nurush Syahadah Mahmud* \\ Centre for Building, Construction, and Tropical Architecture (BucTA), Faculty of Built \\ Environment, University of Malaya (UM), 50603 Kuala Lumpur, Malaysia
}

*nurushsyahadah@gmail.com

Received: 08 August 2017 Final Version Received: 12 June 2018

\begin{abstract}
Sustainability commonly denotes an integration of economic, societal, and environmental domains giving rise to the concept of livable built environment. Progressively, environmental consideration in low carbon repair appraisal for heritage buildings has become increasingly critical and this paper supports this expanding area. This paper gives insight on how 'Green Maintenance' concept and methodology was adopted to appraise low carbon repair works for laterite stones of St Paul's Church, located at the Historical City of Melaka, Malaysia. Subsequently, this paper also highlights the common techniques and materials for laterite stones repair. This has been achieved through quantification of embodied carbon expenditure expended in laterite stones repair within 'cradle-to-site' boundary of Life Cycle Assessment (LCA), using formulaic expression and calculation procedure of 'Green Maintenance' model. The calculation procedures of the model were adopted to enable the evaluation of carbon dioxide $\left(\mathrm{CO}_{2}\right)$ emissions, in terms of embodied carbon expenditure, expended from laterite stones repair for selected case study. The results revealed that stone replacement is considered as the most sustainable repair technique, mainly due to its high longevity of repair and low embodied carbon expenditure, in terms of generated Environmental Maintenance Impact (EMI) of 'Green Maintenance' modelling. However, it may lead to a further discussion in term of philosophical context. As guidance, the EMI model relays the true value of $\mathrm{CO}_{2}$ emissions, contextualised within the longevity of repair and minimal intervention that allows low carbon repair appraisal within livable built environment domain.
\end{abstract}

Keywords: Green Maintenance, Heritage Buildings, Sustainable Repair, Laterite Stones, Life Cycle Assessment (LCA), Environmental Maintenance Impact (EMI)

\section{INTRODUCTION}

Heritage buildings continue to perform their irreplaceable role as representation of history, architectural, cultural, political, spiritual and symbolic value that is passed down from one generation to another (Fielden and Jokilehto, 1993). The number of heritage buildings is expected to represent a significant portion of the building stock in the world (Levine et al., 2007). Without exception, heritage buildings became a key resource in enhancing the livability of a city, specifically for the community that lives in the historic environment (UNESCO, 2013). The discourse of heritage building conservation particularly in maintenance and repair has shifted to an innovative level of livability concept and towards the sustainability agenda revolving around cost analysis such as life cycle costing (Rahim, et al., 2016). This shift aimed to ensure a meaningful benefit over the investment in maintenance that sensitively includes conservation philosophical debate such as least intervention, like for like material, honesty, integrity etc to ensure high quality of intervention (Bell, 1997). The success of maintenance intervention for heritage buildings is therefore not only evaluated based on the quality of the repair, but also conformity to the idea of livable concept and sustainability agenda, in turn, reflects the environmental features settings (Perkins, 2008). Significantly, the question raised is how philosophical vs. cost-guided maintenance may be beneficial to lessen the environmental impact while ensuring the survival of heritage buildings as well as efficiently responds to the needs of the society and the environment they inhabit. The 'Green Maintenance' concept and methodology have been introduced to support sustainability agenda that call for protection of cultural significance while preserving the other capitals such as economy and environmental aspect (Kayan, 2017).

Figure 1 denotes the traditionally accepted conceptual model of sustainability viewed within the environmental, societal and economic context. Meanwhile, the subset of the 
context takes philosophical factor, cost and low environmental impact factor into the evaluation of maintenance for heritage buildings. The intervention (repair technique) undertaken that comply with the three factors will be considered as being the most sustainable concept and method for maintenance i.e. 'Green Maintenance' (Kayan et al., 2018).

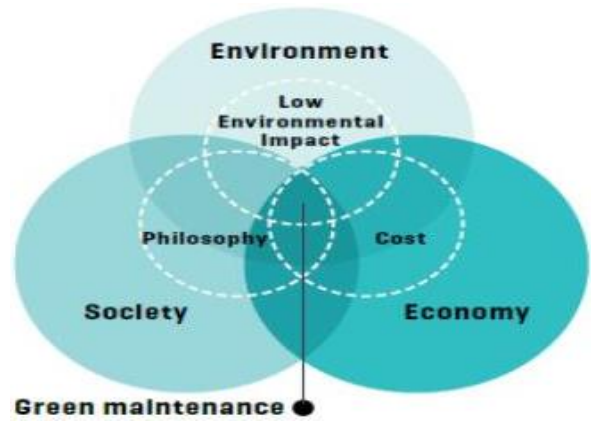

Figure 1: 'Green Maintenance' concept

Source: Forster et al., (2011) and Kayan et al., (2017)

From the environmental perspective, considerable assessment and methodologies such as GBI, BREEAM, GREENSTAR, GreenPASS, NaTHERS, GASSIC, etc., had been developed and revised to reduce the carbon dioxide $\left(\mathrm{CO}_{2}\right)$ emissions (Annuar et al., 2014). Some methods were remained purely on theoretical state and only applicable for a new building (Moncaster, 2015). The evaluations of $\mathrm{CO}_{2}$ emissions for heritage buildings are relatively complex due to the retention of cultural significance and obviously demand a huge amount of cost (Kayan and Forster, 2009). The discussion of $\mathrm{CO}_{2}$ emissions associated with heritage buildings strictly focused on improvement of the mechanical system regards to their comfort and energy efficiency, as the old building cannot perform as newly built in term of their energy (Loron et al., 2015).

Conversely, any alteration process for mechanical installation would also contribute to the high number of $\mathrm{CO}_{2}$ emissions due to a material requirement that needs to be considered in future. Theoretically, maintenance and repair of heritage buildings have a significant role to reduce $\mathrm{CO}_{2}$ emissions in terms of energy and embodied carbon. Embodied carbon is defined as $\mathrm{CO}_{2}$ emissions released through the process of extraction, manufacturing, processing, transportation of materials that consume a fair amount of energy in terms of electricity and fuels in maintenance and repair (Giesekam et al., 2016). The fact is that $10 \%$ of $\mathrm{CO}_{2}$ emissions were contributed from the material sector with a proportion of
$70 \%$ and $15 \%$ associated with manufacturing and transportation respectively (English Heritage, 2007: Rawlinson and Weight, 2007). In the past, building materials were easy to find and locally source with minor impact on transportation. However, due to the scarcity of the material, local products are almost impossible to find, leading to travel between extraction, production or processing site and the construction site influences on fuel consumption, coupled with the weight of materials and transportation mode makes it worse (Lavagna, 2012). Given the complexity, maintenance and repair of heritage buildings have a clear relationship to the observed current scenarios of embodied carbon expenditure in terms of the frequencies of maintenance interventions underlined by 'Green Maintenance' methodology.

To attain rational use of 'Green Maintenance', the embodied carbon expenditure of the repairs must be evaluated using comparable, reproducible methods (Kayan, 2013). Every intervention is also influenced by many variables; longevity of repair, resourcing and geographical location, technological development, mode of transportation, the degree of exposure, building detailing, quality of initial work and specification that should be considered. Therefore, this paper aimed to extend the practicality of the model by testing it to the case study of laterite stone building ( $\mathrm{St}$ Paul's Church) located in the Historical City of Melaka, Malaysia. Progressively, 'Green Maintenance' concept and methodology will be positively welcomed as our society moves towards a low carbon economy and materials and 'green' procurement (Ministry of Natural Resources of Environment Malaysia, 2015). It also can be converted into a supplementary financial cost in maintenance decision-making process as envisioned by sustainable repair approach.

\section{2. 'GREEN MAINTENANCE' METHODOLOGY}

LCA is a science-based, comprehensive and standardised embodied impact studies certified under ISO 14040-14044 that comprises of 4 stages in assessment - goal and scope definition, lifecycle inventory (LCI) studiesrelated to the selection of database, impact analysis and interpretation (Anderson, 2012). The adoption of LCA in 'Green Maintenance' clearly prioritises low carbon materials and repair techniques either single or combination in the maintenance period particularly to 
understand on what to select and how to improve from the quantification of $\mathrm{CO}_{2}$ emissions (Guinée, 2002). The quantification would cover the extraction of raw materials to the end of the product's lifetime or 'cradle-tograve' of LCA boundaries, but in acquiring accurate result, the measurement is limited to 'cradle-to-site' analysis (raw material extraction and processing, transportation, manufacturing, transportation to the building site) (Forster et al., 2011).

Conceptually, Figure 2 sets out an insight on the relationship between each maintenance intervention that is characterised by its longevity $(l)$ and embodied carbon expenditure $(\mathrm{C} e)$ on the service graph condition. The downward sloping signifies the declining condition of the buildings over the life cycle of repair. Each maintenance intervention is important to keep the buildings at the optimal service condition and sustain the performance of the buildings, but it also contributes to $\mathrm{CO}_{2}$ emissions (Blessing et al., (2015). Hypothetically, the more frequent of maintenance intervention, the greater embodied carbon expended (Forster et al., 2011 and 2013). Thus, 'Green Maintenance' gives the preference to the repair technique that has high longevity which incurred a lesser number of repeating interventions and number of embodied carbon expenditure over the lifespan of the building.

This paper practically applies a mathematical modelling method to quantify $\mathrm{CO}_{2}$ emissions that was developed by Forster et al., (2011) and reflects the growing importance of the meaningful determination of carbon cost associated with repair interventions. Forster et al's (2011) work into 'Green Maintenance' was developed from mid-stage doctoral research undertaken by Kayan (2013). Notably, this current paper is a logical and meaningful continuation of Kayan's (2013) doctoral research and practically applies the established theory and mathematical modelling (see Equation 1). As previously mentioned, every intervention is also influenced by other variables including material durability, the degree of exposure, building detailing, quality of repair and specification that will differ from one case to another case study. For example, the lesser durable material may not consume a significant amount of energy during production, but it may require frequent replacement and resulting a higher total embodied carbon in maintenance. Today, the cost implications of repairs must be considered within the context of the associated carbon expenditure. These measures are increasing in prevalence and form a part of carbon reduction strategies.

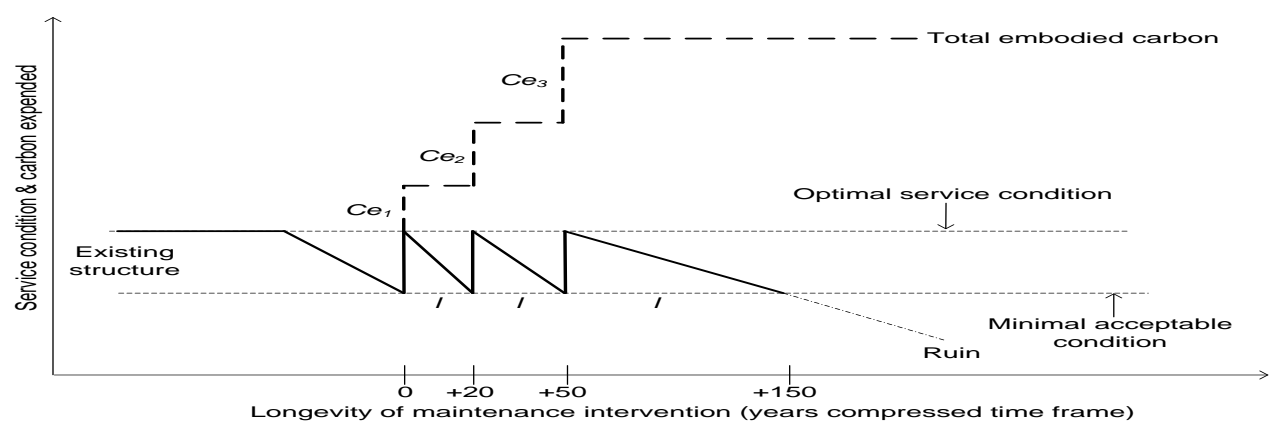

Figure 2: Relationship between longevity of repair and embodied carbon expenditure. Source: Forster et al., (2011 and 2013), Kayan (2013)

The total embodied carbon expended in the maintenance and repair can be calculated through a simplified calculation procedure in the following equation:

Equation (1):

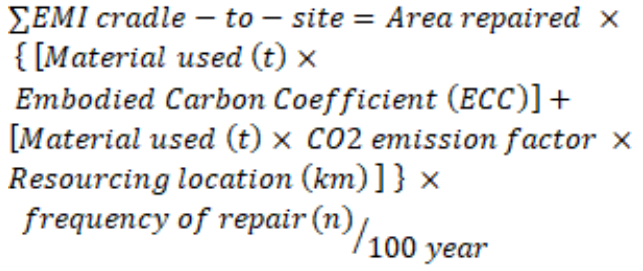




\section{CASE STUDY}

This paper adopts case study approach associated with the usage of multiple sources of evidence and strong context (Knight and Ruddock, 2008). Document of historical maintenance data, records of laterite stones repair is clearly a pivotal consideration in determining case study approach. However, the current fashion of documentation applied by the conservation authorities is still incomplete and make the quantification and analysis unattainable. Practically, direct appointment to the contractor is a common practice if the project is less than RM25,000 and any bigger scale of conservation works are only well documented after the formation of Jabatan Warisan Negara in 2005, where the available data for St Paul's Church is up to 2012. Uncertainty of data was then clarified by the unstructured interview between collaborative partners (Perbadanan Muzium Melaka and Jabatan Warisan Negara), multiple secondary data resources and measuring survey. Due to data discrepancies, English Heritage (2013) had developed a guide to good recording practice in collecting data. It is important to note that there is no simple formula to determine any survey techniques for recording purpose where it depends on situation and requirement of the audience. In this paper, data collection are associated with the area of wall repaired measured in $\mathrm{m}^{2}$ and material quantities involved in repair denoted in the conservation report secondary data sources and unstructured interviews with experts. Meanwhile, photography tool, basic survey tool (e.g. direct measurement using tapes and rods) and written description are fully integrated into the process of creating the maintenance records.

\subsection{ST PAUL'S CHURCH BUILDING PROFILE}

St Paul's Church is the oldest European building in Southeast Asia located on the summit of St Paul's Hill or known as Bukit Melaka, representing a network of Portuguese, Dutch and British colonials (Figure 3). First built in the- 1560 by Duarte Coelho and enlarged by Jesuits using laterite block as the main building material. A glance at the physical appearance as it exists today clearly explains the different timelines of construction. It comprised thicker wall as indicative of the additional strength need to support an upper floor and high towers, a hundred feet tall to its pyramidal roof and reinforced at ground level with a central pillar (Tan, 2015)

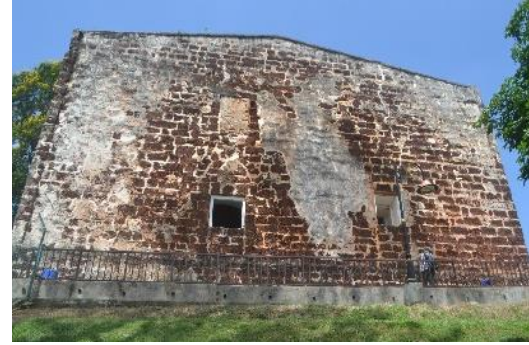

Figure 3: St Paul's Church

Historically, St Paul's Church endured adaptive change of use from college to hospital. However, due to its prominent location, it had been converted into a partially military function, as it became a prime target of bombardment by Portugal's enemies (Tan, 2015). Subsequent repairs in order to increase the strength of the structure were executed by using coral rock as filler during Portuguese's era and brick (yellow coloured brick and plastered) during Dutch's occupation (Khoo, 1976). After the establishment of Christ's Church during the Dutch's rule, St Paul's Church was left as a graveyard. However, the British had continued to utilise the structure for a military purpose until the series of demolition work of Melaka Fort were committed. Until 1930 , the church was neglected until a series of renovations led by the Melaka Historical Society and now is being conserved as part of national heritage properties (Tan, 2015). In a glance, history had shown the capability of laterite stone as building material to stand nobly for more than 500 years, endure through conflicts and war and now with the test of time under tropical hot climate. From the perspective of maintenance and repair, it may influence the longevity of repair. Theoretically, the faster the rate of deterioration of repair materials, the more frequently the repair is required i.e. the larger the deteriorated area, the higher total area repaired (Kayan, 2013).

3.2.

BUILDING MATERIALS OF ST PAUL'S CHURCH

Table 1 summarised the construction material for St Paul's Church exposed external wall part generated from site survey and mathematical calculation. It is believed that the laterite stones are locally sourced from Ilha das Pedros (Pulau Upeh, Melaka, Malaysia) and Cape Ricado (Port Dickson, Negeri Sembilan, Malaysia near Lukut Fort) where the fact can be seen on laterite cutting over the island, surrounding area and salvaged material from other buildings built by Portuguese and Dutch (Khoo, 1998). 
Presently, however, there are no active stone quarries within the area due to their closure (Ibrahim, 2007)

Laterite stones for St Paul's Church are ferruginous deposits of vesicular structure, soft until it can be cut using a spade, to be made into a regular block in fresh state (Pendleton, 1941). After it has been cut, it will rapidly harden and highly resistant to weathering due to the process of crystallisation components of iron content of sesquioxides that consists of three atoms of oxygen with two atoms or radicals of clay soils (Ahmad and Hoe, 2002). Physically, it is commonly a purplish or brick-red; porous rock, passing into liver brown perforated by numerous sinuous and tortuous tubular cavities either empty, filled or partially filled with a greyish-white clay which may changing into an ochreous (brownish-yellow), reddish and yellow-brown dust or with a lilac-tinted lithomargic earth (decomposed rock) (Pendleton ,1952). Beyond the uniqueness, little empirical research has been done for this material particularly on maintenance and repair, as required by conservation and master plan (Kayan et al., 2017). Consequently, their maintenance and repair demanded attention in the Conservation Management Plan for Melaka (CMP) UNESCO World Heritage Site regarding to appropriate treatment, materials, methodologies, techniques and workmanship. Kayan (2006) expounded that, in the Malaysian context, 'conservation management plan' (CMP) of Section 97 of National Heritage Act 2005 (Act 645) shared similarities of conservation (Kayan, 2006) and master plan (Luiza et al., 2017).

Table 1: Construction Material of St Paul's Church

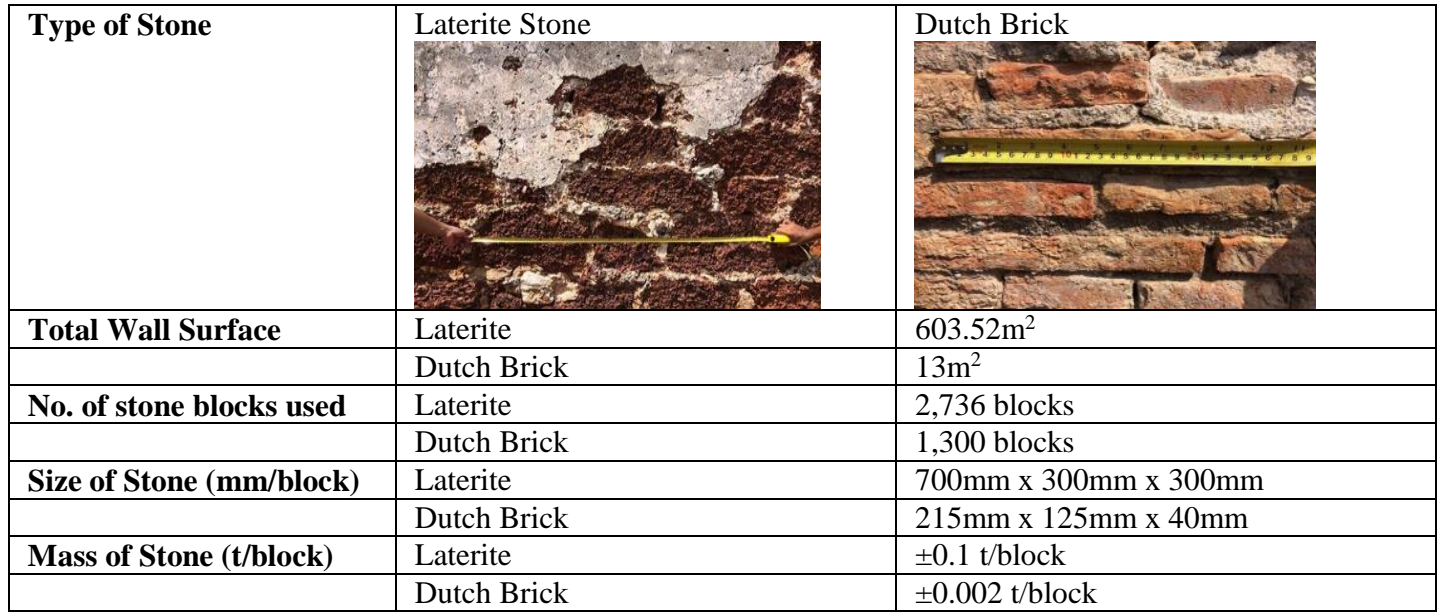

Meanwhile, a great deal of lime stone was required for the construction of Paul's Church. However, there is no exact proportion recorded in any maintenance document. By using various literatures to fit the purpose of this paper, Khoo (1998) distinguished two generation of concrete and mortar based on Barmen (1986) definition, seen to cross-cutting each other. The early mortar is a composition of lime and sand that is visible within the layer of smooth rounded pebbles of laterite with some other materials (e.g. coral, angular pieces of charcoal and exfoliating oyster shells) (see Figure 4). Meanwhile, the later mortar is, in part with a better workmanship compared to an early mortar. It composed of evenly sorted sand matrix up to coarse but not granules as found in an early mortar (Figure 5). To physically differentiate, the early mortar is commonly used in laterite structure meanwhile the later mortar is used to fill up voids in laterite blocks and found usually bits with pieces of broken bricks (aggregates). Brick is also used to fill the void of buildings. It can be interpreted that early work is primarily done by the handiwork of Jesuit and later with broken brick aggregates by Dutch workmanship (found to be similar in the Stadhuys buildings that lined by bricks). However, the original structure has been cemented by modern mortar (see Figure 6) that overprints the early and later mortar.

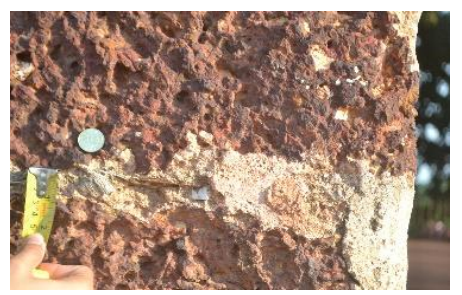

Figure 4: Early mortar for jointing material 


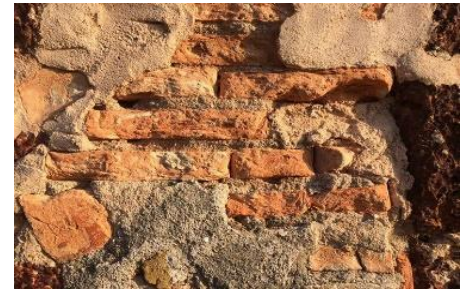

Figure 5: Later mortar for brick structure

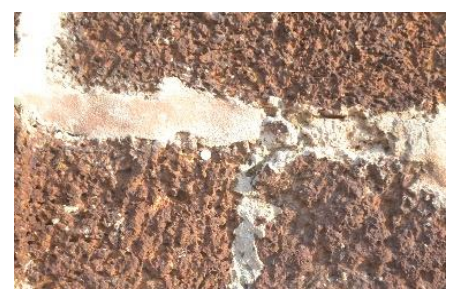

Figure 6: Modern mortar for pointing

For quantification, assumed that the proportion of 1:3 of limestones, sand is allocated for early mortar, 1;1;2 of limestones, brick dust and sand for the later mortar (Matias et al., 2016) and modern mortar referred to lime mortar materials applied in the reconstruction of Bastion Middelburg (1;1;3 limestones, white cement and sand). Prior to the repair works, appointed contractor should undertake analysis on lime mortar profiles. This is mainly to determine the proportion; started with selecting several samples of the existing pointing from different spot of wall surface. These samples were taken to lab to be analysed to determine the compositions, mixture, proportion and respective resourcing location. The nature of repair for St Paul's Church might differ from other laterite stone structures within the area of Historical City of Melaka where several ordinary interventions had been done partially with guidelines and only after the establishment of Jabatan Warisan Negara in 2008.

\subsection{REPAIR TECHNIQUE AND SCENARIOS}

Generally, there are four (4) repair techniques known as stone replacement, plastic repair, repeated repointing and pinning and consolidation that could be utilised due to relative levels of intrusion to the original fabric (Kayan, 2013). Several scenarios within arbitrary maintenance period could be considered as it may bring a number of benefits relating to the technical and philosophical aspect of masonry conservation (Forster, 2010). For example, repeated repointing on deteriorated mortar joints would have a limited effect on adjacent laterite structure (Kayan, 2013). In contrast, the removal of deteriorated laterite stone and replacement with a new stone block unit logically requires removal of greater quantities of original fabric (Torney et al., 2014). It must be noted that certain combinations of laterite stones repair are more common than others. For example, the stone replacement would be practically done only once, while a plastic repair is commonly followed by natural stone replacement within a selected arbitrary maintenance period (Kayan et al., 2017). Conversely, it would be highly unusual to replace the stone and then undertake a plastic repair within the same period (Forster et al., 2011 and Kayan, 2013). In the case of St Paul's Church, it is identified that there are three (3) repair techniques that are mainly utilised and will be modeled with their Environmental Maintenance Impact (EMI) over 100 years based on previous literature (Forster et al., 2011 and Kayan et al., 2017). Figure 7 shows the four (4) scenarios are defined for maintenance of $1 \mathrm{~m}^{2}$ of area for laterite stone structure over a study period of 100 years.

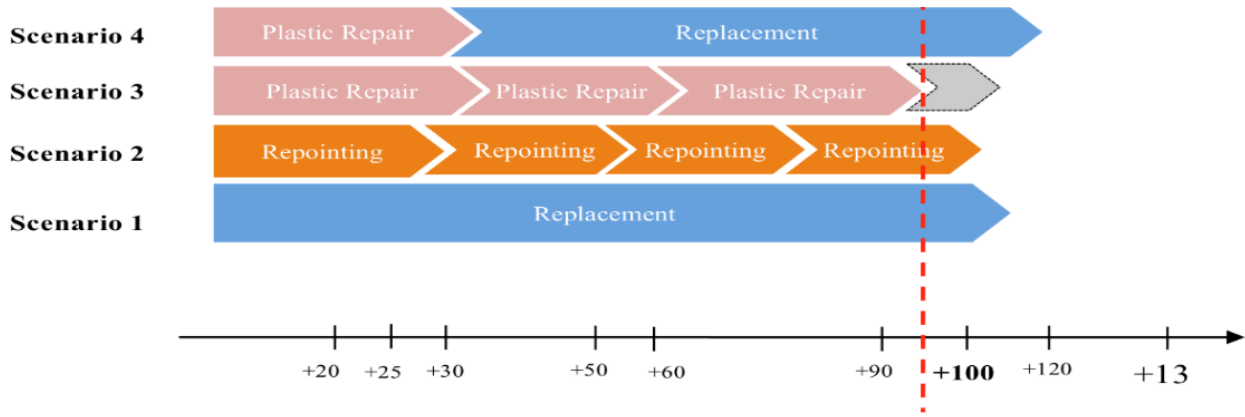

Time frames (years)

Figure 7: Repair Scenario and time frames.

Source: Adopted from Kayan et al., (2017) 


\subsubsection{Scenario 1: Stone replacement}

Based on Figure 7, stone replacement is a repair involves in the serious decayed stonework. It is necessary to dig out the decayed stone, replace it with the matching one (Hyslop, 2006). In this case, it is found that bricks were alternatively used for replacement of laterite stones (see Figure 8). Technically, it requires cutting back of approximately $100 \mathrm{~mm}$ of the defective material and building in a new section of stone (Forster et al., 2011). Practically, there will be a limited choice for replacement and the new stone need to undergo some complex process such as quarrying, extracting, processing and transporting that may be incurred high-energy usage, which contributes to high-embodied carbon (Hu and Wang, 2006), despite adoption of green reconstruction of the existing buildings (Hu and Wang, 2016). But, the life expectancy of 100 years may lead less maintenance intervention in a study period.

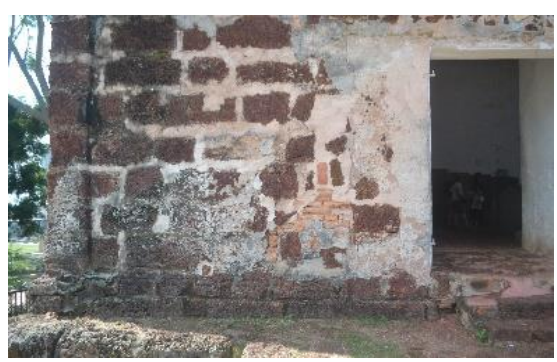

Figure 8: Usage of brick for stone replacement

\subsubsection{Scenario 2: Repeated repointing}

Repointing is the most common technique to repair loose open, crumbly and washed-out bedding and jointing mortar of wall (Dore et al., 2013) (see Figure 9). Normally, the mixture consists of binders, sand or is available in a premixed form. Dealing with defect and decay, repointing requires cutting out failed joint mortar (removal of at least $3 / 4$ of an inch deep old mortar) and applying new mortar for finishing in order to replicate the original mortar style (Durnan and Muir, 2006). The rule of thumb is if there is more than $25 \%$ of the wall that needs to be repointed, it is effective to repoint the entire wall structure and applying the correct tool such as thin chisel or pointing tools with skilled craftsmen (Historic Scotland, 2007). The new material should be tooled to mimic the old joint profile in terms of visual and performance of structure and repointing in excessively hot, cold or rainy conditions should be avoided (Foulks, 1997). Besides, durability of repointing will depend on two factors such as mortar used, finish profile given to the face of the joint and the workmanship as it may incur frequent intervention and lead to high number of $\mathrm{CO}_{2}$ emissions. A normal expectation for repointing is at least 25 years, incurs 4.0 times of its EMI to 100 years of the study period (see Figure 7) (Kayan et al., 2017). The bulk volume or quantity of material may crucial as it may deal with a large area of repair, increase the usage of material and its production.

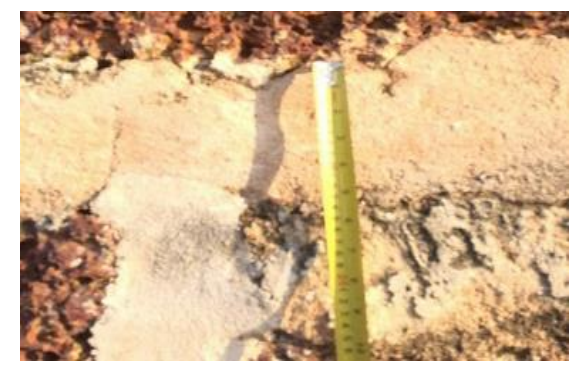

Figure 9: Pointing technique, 50-100mm of thickness

\subsubsection{Scenario 3: Repeated plastic repair} Commonly, plastic repair involved in serious decayed stonework related to the surface area that also known as mortar repair (Ashurt and Ashurt, 1988). Typically, the decayed stone needs to be cut back and lime-based mortars are applied to the surface of stone (Hyslop, 2006). In this case, this technique is limited to plastering and patching purpose (see Figure 10). The longevity of this technique is generally last for only 30 years and reapplied every 30 years periodically (3.33 times in the study period)(see Figure 7) (Forster et al., 2011 and Kayan, 2013).

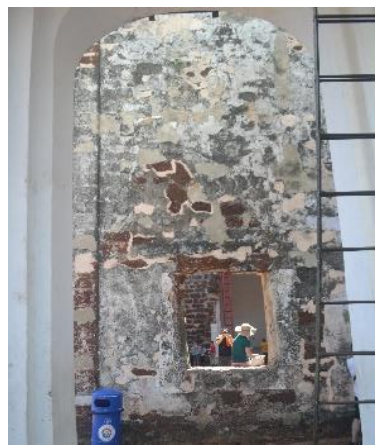

Figure 10: Mortar patch over the laterite surface

\subsubsection{Scenario 4: Plastic repair, then stone replacement}

As previously discussed in scenario 3, high level of deterioration may lead to further 
intervention such as stone replacement. In this situation, plastic repair and the decayed stone will be removed after 30 years and will be replaced by the new stone. Similar to scenario 2 , the replacement will last beyond 100 years in a study period and the EMI in this study is 0.7 (Kayan, 2013) (see Figure 7).

\section{TESTING OF 'GREEN MAINTENANCE'}

Based on scenarios and data collected, Table 2 highlights the total mass of materials required for $1 \mathrm{~m}^{2}$ of functional unit and overall external wall area $\left(616.52 \mathrm{~m}^{2}\right)$ repaired for respective laterite stones repair options. Based on Table 2, each repair options were attributed by the mass of stone (tonnes/t), a dimension of stone blocks specifically for stone replacement, lime mortar jointing ratio, pointing thickness and depth of the wall, minimum depth undercut or cutback base coats and later patch finishes. Testing on the Green Maintenance model and calculation inputs explained in this section will be utilised to compare the embodied carbon expended in laterite stone repair within 'cradle-to-gate' and 'gate-to-site' of LCA with respective a longevity of laterite stones repair (EMI attribute) within maintenance arbitrary period (100 years).

Table 2: Detail material in $\mathrm{t}$ for repair technique per $1 \mathrm{~m}^{2}$ and the overall total external wall surface

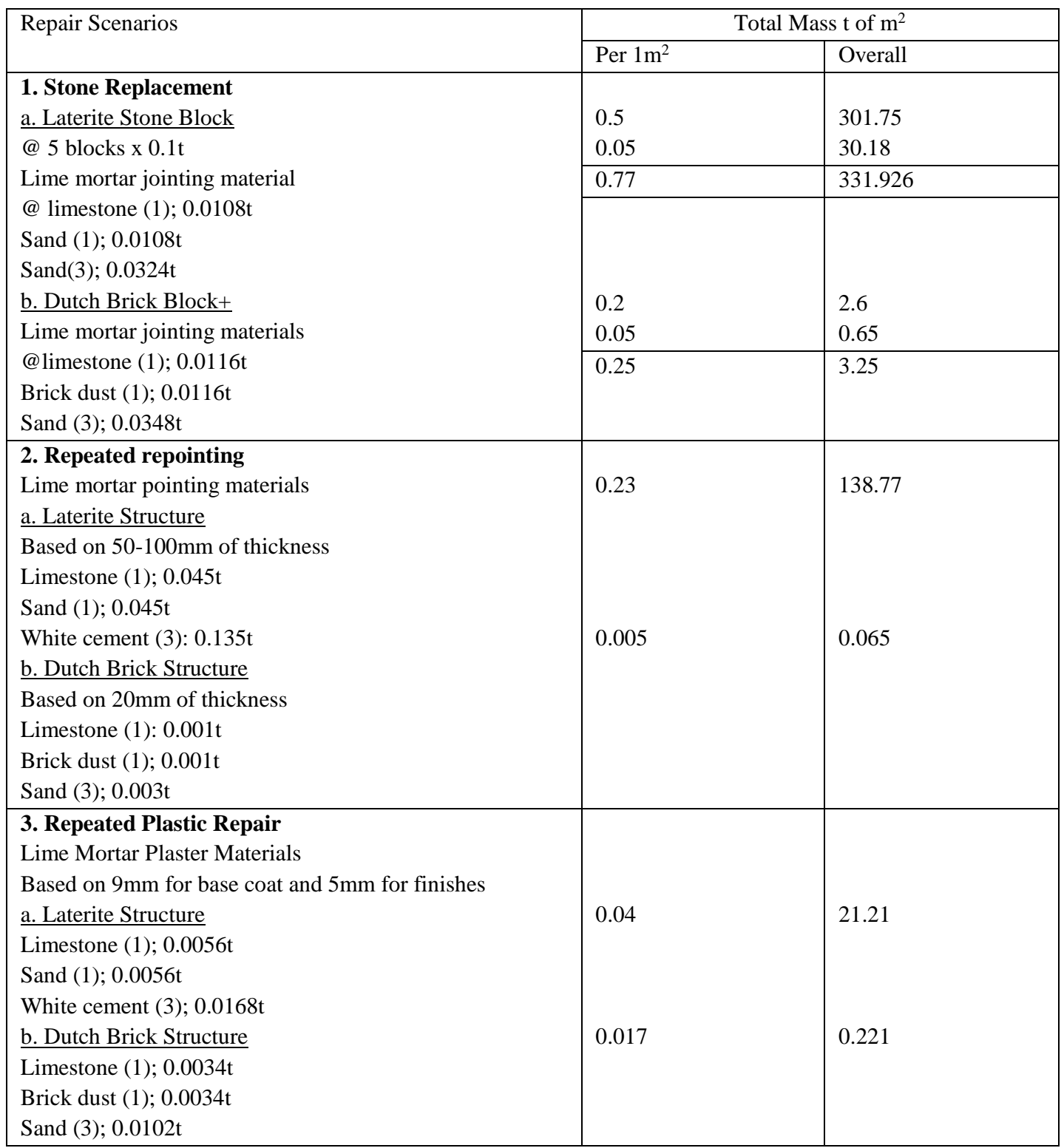




\begin{tabular}{|l|l|l|}
\hline 4. Plastic Repair, Then Stone Replacement & & \\
a. Lime mortar plaster materials + (Stone Replacement for & 0.04 & 21.21 \\
Laterite Block + Lime mortar jointing material) & 0.5 & 301.75 \\
& 0.05 & 30.18 \\
\cline { 2 - 3 } b. Lime mortar plaster materials + (Stone Replacement for & 0.59 & 353.14 \\
\cline { 2 - 3 } Brick Stone + Lime mortar jointing material) & 0.017 & 0.221 \\
& 0.2 & 2.5 \\
\cline { 2 - 3 } & 0.05 & 0.65 \\
\cline { 2 - 3 } & & 3.371 \\
\hline
\end{tabular}

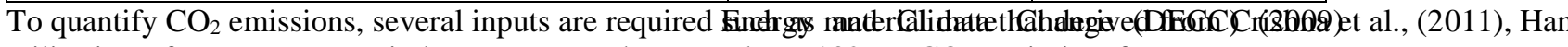
utilisation of open access to industry-generated value in ICE database would increase the quality of this paper. This paper uses primary energy sources (such as coal and electricity) if they are relevant in this quantification. Meanwhile, transportation data ('gate-to-site') derived from Department of Environment and Rural Affairs (DEFRA) and Department of where $132 \mathrm{gm} \mathrm{CO}_{2}$ emission factor per tonne$\mathrm{km}$ or $1.32 \times 10^{-4} \mathrm{kgCO}_{2}$ based on Heavy Good Vehicle (HGV) in the UK for 2005. $\mathrm{CO}_{2}$ emission factor will be multiplied by a weight of good and distance (shortest and most direct distance travelled from resourcing location) to building site (see Table 3 ).

Table 3: Inputs required for calculation

\begin{tabular}{|l|l|l|}
\hline Material & ECC(kgCOe) & Resourcing Location \\
\hline Laterite Stone & 0.781 & Salvaged Material* $^{*}$ \\
\hline Brick & 0.060 & $\begin{array}{l}\text { Salvaged Material* and Tajida Industries Sdn Bhd, Krubong, Melaka, } \\
\text { Malaysia (15.6km) }\end{array}$ \\
\hline Limestones & 0.017 & Kuari ISB Sdn Bhd, Alor Gajah, Melaka,Malaysia (46.1km) \\
\hline Sand & 0.005 & Bukit Senggeh, Selandar, Melaka, Malaysia (37.7km \\
\hline Brick Dust & 0.22 & Nurul Huda Sdn Bhd Alai Kandang Tengah (8.7km) \\
\hline $\begin{array}{l}\text { White } \\
\text { Cement }\end{array}$ & 0.459 & Tan Soon Hin Trading Sdn Bhd, Klebang Besar, Melaka, Malaysi a (7.9km) \\
\hline
\end{tabular}

Note* The value of 0 for ECC will be utilised prior to the usage of salvaged material. There might be a secondary process where the stone need to be recut (brick) or brick dust manufacturing. In this case, in the bigger scale of project, it is assumed those salvaged material need to be processed which lead to the contribution of $\mathrm{CO}_{2}$ emissions.

Several resourcing location is taken from Azizul (2015), Azaman (2017) and Non-metal Distribution Map from Jabatan Mineral and Geosains (2007)

\section{RESULT AND DISCUSSION}

This section discusses embodied carbon expended of repair options represented by different scenarios (either single or combination of repair techniques) using 'Green Maintenance' model's calculation procedure. Primarily, the generated results of environmental impact $\left(\mathrm{CO}_{2}\right.$ emissions) viewed in $\mathrm{kg} / \mathrm{CO}_{2} \mathrm{e} / \mathrm{t} / \mathrm{m}^{2}$ per $1 \mathrm{~m}^{2}$ of wall repaired or overall external wall of St Paul's Church $\left(616.52 \mathrm{~m}^{2}\right)$ that will beneficial to align the knowledge of conservation philosophy (ethics and principles) and cost as envisioned by 'Green Maintenance' concept, mainly to assist a decision making process to select most sustainable repair.

\subsection{Total $\mathrm{CO}_{2}$ Emissions $\left(\mathrm{KgCO}_{2} \mathrm{e} / \mathrm{t} / \mathrm{m}^{2}\right)$ Functional Unit for $1 \mathrm{~m}^{2}$}

Table 4 establishes functional units of $\mathrm{kgCO}_{2} \mathrm{e} / \mathrm{t} / \mathrm{m}^{2}$ or a normalised overall total of embodied carbon expenditure on laterite stone repair, undertaken on $1 \mathrm{~m}^{2}$ of wall repaired area of St Paul's Church. Ultimately, this carbon figure could be used to generate a formalised inventory of laterite stone repair techniques specifically for any future conservation project of St Paul's Church. From Table 4, it can be concluded that stone replacement would likely have a significant environmental impact of $\mathrm{CO}_{2}$ emissions rather than repeated repointing, repeated plastic repair per intervention. However, the testing of total EMI evaluation linked with the appraisal of cumulative effect of maintenance in 100 years with their respective longevity of repair (number of intervention) had prevailed a significant increment of total embodied carbon expenditure $\left(\mathrm{CO}_{2}\right.$ emissions) of other repair scenarios as well (see Total Average EMI for scenario 2 and 3). Special cases where denoted in Scenario 4 in Table 4, 
where stone replacement needs to be done immediately after the life expectancy of plastic repair contributed relatively high $\mathrm{CO}_{2}$ emissions compared to the single repair of stone replacement in Scenario 1. Therefore, the principles of minimal intervention underlined in philosophical knowledge could be tailored with the following carbon figure.

Practically, however, in the context of maintenance of heritage building in Malaysia, budget allocation is always related to the aim of tourism industry. For instance, $63 \%$ of RM442.2 billion named under Eighth and Ninth Malaysian Plan was purposely allocated for the conservation of cultural heritage (Mustafa and Abdullah, 2013). Evidently, the availability of maintenance's record for St Paul's Church is bounded only for bigger scale of conservation project (disbursement up to RM25,000) parallel to the Malaysian Plan. To facilitate a number of frequent interventions is almost unfeasible where the principles of minimal intervention that contributed to relatively less $\mathrm{CO}_{2}$ emissions will be beneficial in a small-scale project. Meanwhile, Total Environmental Maintenance Impact (EMI) in the later section will discuss the number of $\mathrm{CO}_{2}$ emissions in the large scale of the conservation project and in 100 years.

Table 4: Embodied carbon per $1 \mathrm{~m}^{2}$ in $\mathrm{kgCO}_{2} \mathrm{e} / \mathrm{t} / \mathrm{m}^{2}$ associated with repair scenarios within 100 years arbitrary period

\begin{tabular}{|c|c|c|c|c|c|}
\hline & & $\begin{array}{l}\text { Scenario 1 } \\
\text { Stone } \\
\text { replacement }\end{array}$ & $\begin{array}{l}\text { Scenario 2 } \\
\text { Repeated } \\
\text { repointing }\end{array}$ & $\begin{array}{l}\text { Scenario } 3 \\
\text { Repeated } \\
\text { plastic repair }\end{array}$ & $\begin{array}{l}\text { Scenario } 4 \\
\text { Plastic repair, then } \\
\text { stone replacement }\end{array}$ \\
\hline \multirow{3}{*}{$\begin{array}{l}\text { Stone } \\
\text { replacement }\end{array}$} & $\mathrm{kgCO}_{2} \mathrm{e} / \mathrm{m}^{2}$ & $\begin{array}{l}\text { L:0.406 } \\
\text { B: } 0.015\end{array}$ & - & - & $\begin{array}{l}\text { L; } 0.406 \\
\text { B; } 0.015 \\
\end{array}$ \\
\hline & $\begin{array}{l}\text { Number of } \\
\text { intervention (n) }\end{array}$ & 1 & - & - & 0.7 \\
\hline & $\begin{array}{l}\text { Total Average } \\
\text { EMI }\end{array}$ & $\begin{array}{l}\text { L; } 0.406 \\
\text { B; } 0.015\end{array}$ & - & & $\begin{array}{l}\text { L; } 0.284 \\
\text { B; } 0.010 \\
\end{array}$ \\
\hline \multirow{3}{*}{$\begin{array}{l}\text { Repeated } \\
\text { Repointing }\end{array}$} & $\mathrm{kgCO}_{2} \mathrm{e} / \mathrm{m}^{2}$ & 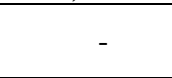 & $\begin{array}{l}\mathrm{L} ; 0.063 \\
\mathrm{~B} ; 0.006\end{array}$ & - & 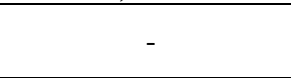 \\
\hline & $\begin{array}{l}\text { Number of } \\
\text { intervention }(\mathrm{n})\end{array}$ & - & 4 & - & - \\
\hline & $\begin{array}{l}\text { Total Average } \\
\text { EMI }\end{array}$ & - & $\begin{array}{l}\text { L; } 0.252 \\
\text { B; } 0.024 \\
\end{array}$ & - & - \\
\hline \multirow{3}{*}{ Plastic repair } & $\mathrm{kgCO}_{2} \mathrm{e} / \mathrm{m}^{2}$ & - & - & $\begin{array}{l}\mathrm{L} ; 0.009 \\
\mathrm{~B} ; 0.001 \\
\end{array}$ & $\begin{array}{l}\mathrm{L} ; 0.009 \\
\mathrm{~B} ; 0.001 \\
\end{array}$ \\
\hline & $\begin{array}{l}\text { Number of } \\
\text { intervention (n) }\end{array}$ & - & - & 3.33 & 1 \\
\hline & $\begin{array}{l}\text { Total Average } \\
\text { EMI }\end{array}$ & & - & $\begin{array}{l}\text { L; } 0.029 \\
\text { B; } 0.003 \\
\end{array}$ & $\begin{array}{l}\text { L; } 0.009 \\
\text { B; 0.001 } \\
\end{array}$ \\
\hline $\begin{array}{l}\text { Total Average } \\
\text { EMI }\end{array}$ & & 0.421 & 0.28 & 0.032 & 0.304 \\
\hline
\end{tabular}

*Note $=\mathrm{L}=$ Laterite $\mathrm{B}=$ Brick

\subsection{Total Environmental Maintenance Impact (EMI) of St Paul's Church}

Previously, Table 4 shows the average EMI undertaken on normalised $1 \mathrm{~m}^{2}$ of wall repaired for St Paul's Church or known as functional units of embodied carbon per $1 \mathrm{~m}^{2}$
$\left(\mathrm{kgCO}_{2} \mathrm{e} / \mathrm{t} / \mathrm{m}^{2}\right)$ and practically applies to small scale of maintenance project. Therefore, the value of functional unit will be utilised in calculating the Total EMI of St Paul's Church by multiplying it with total external wall surface area $\left(616.52 \mathrm{~m}^{2}\right)$ of St Paul' Church (see Figure 11). 


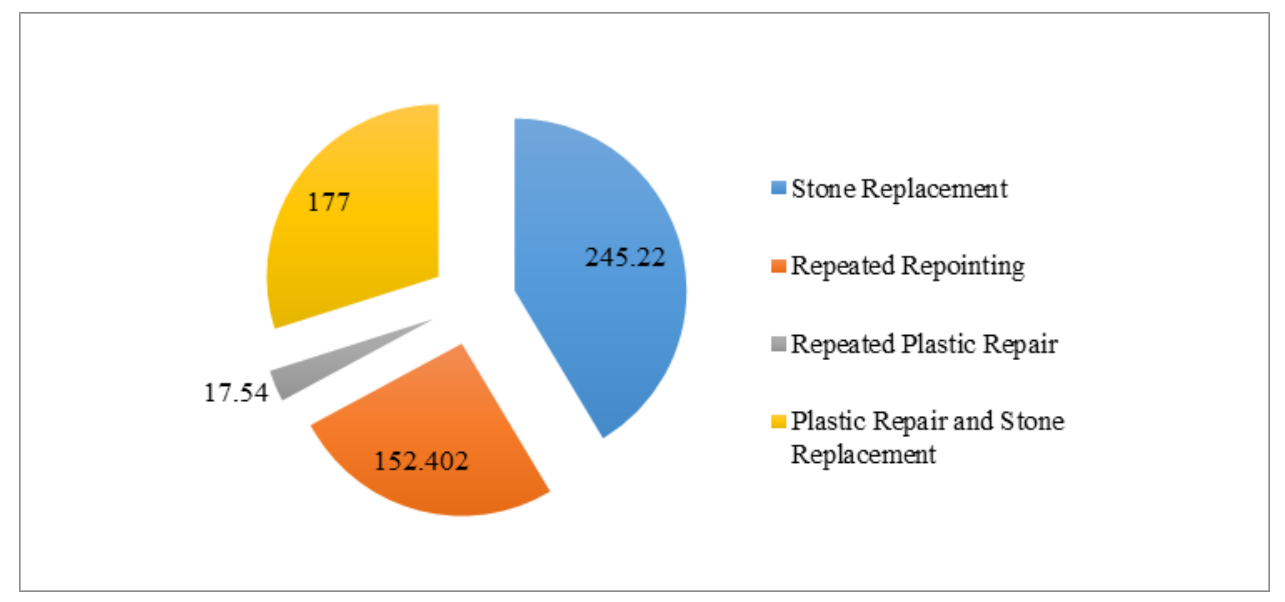

Figure 11: Total generated EMI in $\mathrm{kgCO}_{2} \mathrm{e} / \mathrm{t} / \mathrm{m}^{2}$ for external wall surface area of St Paul's Church

Figure 11 and Table 4 evidently shows that stone replacement (Scenario 1) has the highest embodied carbon expenditure either in $1 \mathrm{~m}^{2}$ and the Total Generated EMI over the wall surface $\left(0.421 \mathrm{kgCO}_{2} \mathrm{e} / \mathrm{t} / \mathrm{m}^{2}\right.$ per $1 \mathrm{~m}^{2}$ and 245.22 $\mathrm{kgCO}_{2} \mathrm{e} / \mathrm{t} / \mathrm{m}^{2}$ ) over 100 years of arbitrary maintenance period. Meanwhile, the results also revealed that repeated plastic repair had a small amount of $\mathrm{CO}_{2}$ emissions $\left(17.55 \mathrm{kgCO}_{2} \mathrm{e} / \mathrm{t} / \mathrm{m}^{2}\right)$ compared to other repair techniques. However, it must be noted that the area of deteriorated wall surface is the important variable that need be considered as the higher the areas need to be re-plastered, more material is required. Subsequently, this situation will lead to high $\mathrm{CO}_{2}$ emissions in a long run. Additionally, it is found that cement-based materials were introduced in the plastic repair technique. In which, they are generally cheaper than lime materials but it is technically incompatible and limits the longevity of repair. In practice, usage of plastic repair technique needs further intervention (e.g. stone replacement) due to its low longevity and lead to a further contribution of $\mathrm{CO}_{2}$ emissions in 100 year (see Figure 11). Based on the Total Generated EMI in Figure 11 , it also revealed that repeated repointing contributes to second highest amount of $\mathrm{CO}_{2}$ emissions $\left(152.402 \mathrm{kgCO}_{2} \mathrm{e} / \mathrm{t} / \mathrm{m}^{2}\right)$ but it has a low initial embodied carbon per functional unit of $1 \mathrm{~m}^{2}$. The huge amount $\mathrm{CO}_{2}$ emissions contributed by this technique shown in Figure 11 were mainly due to the large surface area of deteriorated and quality of workmanship (50$100 \mathrm{~mm}$ thickness of depth). This variable requires a substantial amount of lime mortar and will lead to high amount of $\mathrm{CO}_{2}$ emissions.

The result clearly shows that longevity of repair, number of intervention, area of deteriorated and quality of workmanship will highly influence the selection of the most sustainable repair technique based on their embodied carbon expenditure. Thus, from the results it can be said, stone replacement is an ideal technique to be utilised for heritage building repair. This is mainly due to its high longevity and less intrusion to an original historic fabric. But, it is well recognised that quarrying and processing of natural stone will contribute to high environmental impact (English Heritage, 2007). Hyslop (2004) expounded that stone replacement technique is a challenging demand to find a new stone that is suitably matched and compatible with the underlying substrate. Thus, the usage of locally available and salvaged materials had become a priority for stone replacement. As previously discussed in section 3.3.1 and results from Table 4, it is understood that due to the scarcity issue, brick has been used as alternative materials to repair deteriorated laterite stones of the case study. This led to the philosophical debate in heritage buildings conservation e.g. least intervention, like for like material, honesty, integrity etc. This subsequently demands meticulous view from experts on the 'trade-off' situation between the cost of loss in historic fabric and $\mathrm{CO}_{2}$ emissions (Forster, 2010). Initially, honesty should always be the priority, as the intervention should need to be clearly seen in the fabric. However, over a time, the blurring of the old and new fabric may occur as delamination develops.

In term of $\mathrm{CO}_{2}$ emissions, the usage of salvaged material is emphasised to reduce the $\mathrm{CO}_{2}$ emissions from transportation phase or 'gate-tosite' impact. Azizul (2015) on other hand postulated that imported laterite stone for the reconstruction of Bastion Middelburg from 
Prachinburi in Thailand $(1,797 \mathrm{~km})$ is one of the highest impetus reasons of $\mathrm{CO}_{2}$ emissions. Conversely, it is also found that the usage of sound salvaged material is not easily incorporated in building practices, in which, they require meticulous planning from the start of dilapidation surveys through conservation works in locating the sources of the stone. Sound salvaged repair materials should be carefully cleaned down, sorted to suitable dimensions and arranged in stacks corresponding to their various length (Ashurt and Dimes, 1988). They perhaps can be obtained from various sources such as abandoned old buildings, demolished building structures, building suppliers, salvage contractors and use-material dealers (Ramli and Byrd, 2012). Then, the usage of moderate figure of Embodied Carbon Coefficient (ECC) is stressed for salvaged materials (Laterite and Brick) due to processing process (cradle-togate). It is assumed that the salvaged materials need to be processed (re-cut) and transported in very short distance, logically applied to bigger scale of project.

\section{LIMITATION OF STUDY}

It must be noted from the result that there is a limitation of LCA compilation i.e. assumption and data uncertainty. As previously discussed, the usage of LCA is proven as an environmental management tool to assist the reduction of $\mathrm{CO}_{2}$ emissions but it needs to be enhanced over a time particularly for other exposed element in laterite structure such as foundation part, paint etc. In order to expand the work of this paper, further data exploration, complementary studies and validation from multiple resources need to be undertaken eloquently. Consideration upon limitations in choosing the specific LCA boundary and problems as posed by incorrect assumptions, inaccurate data, varying parameter of repair material, problematic LCI study and different longevity of repair. To increase the quality of future research, transparency (open access data), utilising the comprehensive data in LCI to increase the robustness, direct measurement to the site, application of accurate boundary in maintenance ('cradle-to-site') and usage of rationale comparison between the longevity of repair based on various literature is paramount important.

\section{CONCLUSION}

This paper shows that mathematical calculation procedure of 'Green Maintenance' can be utilised to calculate the total EMI of repair.
Eloquently, the need for strengthening the sustainability of the built heritage in building a livable environment arises. It requires an innovative solution in maintenance with a specific merit. The significant values of heritage building are not solely limited to create a museum piece. But, it also strongly related to the people who live in this area as historic society obligated to maintaining good environment through their decision in maintenance. As the environmental parameter directly affects the quality of life, 'Green Maintenance' is believed to be an approach, applicable in measuring the qualities of any intervention taken to attain balanced in decision making. The model is proven to be a good approach in selecting the most sustainable repair for laterite stone repair. Ultimately, it provides a sustainable solution in selecting repair options based on environmental point of view through low carbon appraisal that promotes low $\mathrm{CO}_{2}$ emissions. Notably, the model also relays 'true' $\mathrm{CO}_{2}$ emissions expended in repair and gives a preference to technique with high longevity and durability i.e. less maintenance intervention. EMI of the model also enables facilitate analysis between philosophies, cost and environmental impact from repair. As the society moving towards low carbon economy, 'Green Maintenance' assists to achieve sustainable repair and livable historic environment.

\section{ACKNOWLEDGEMENT}

This paper is based on on-going research of $\mathrm{PhD}$ thesis entitled 'Quantification of Green Maintenance on Embodied Carbon Expenditure for Laterite Stone Repair: Case Study of Heritage Building Conservation in Melaka", under supervision of Dr Sr Brit Anak Kayan and Dr Noor Suzaini Mohamed Zaid, from Department of Building Surveying, University of Malaya (UM), Kuala Lumpur, Malaysia. Funded by Ministry of Higher Education (MOHE) under Fundamental Research Grant Scheme (FP005-2014A).

\section{REFERENCE}

Ahmad, A.R. and Hoe, T.G. (2002), Laterite Revisited; mode of formation, Proceedings of the Geological Society of Malaysia Annual Geological Conference, Kota Bharu, Kelantan, Malaysia

Anderson, J. (2012) A guide to understanding the embodied impact of construction product, PE International \& Jnae 
Thornback, Construction Products Association, London.

Annuar, M.N., Osmond, P. and Deo, P. (2014). Application of sustainability indicators and rating tools: Envisioning 'Life Cycle' assessment for buildings in Malaysia, Proceedings of the World Sustainable Building 14, Barcelona.

Ashurst, J. and Ashurst, N. (1988), Practical Building Conservation: stone masonry: English Heritage Technical Handbook Volume 1, Gower Technical Press, Avon.

Ashurst, J. and Dimes, F.G. (1998), Conservation of Building and Decorative Stone, Butterworth Heinemann, Oxford and Woburn, Mass.

Azaman, M. M. N. (2017), Quantification of Carbon Emission in Lime Plaster Repair for Heritage Buildings, Undergradute Thesis, University of Malaya, Kuala Lumpur.

Azizul, N.D.A. (2015), Quantification of Carbon Emission in Laterite Stone Repair of Bastion Middelburg, Malacca: A Green Maintenance Approach, Undergraduate Thesis, University of Malaya, Kuala Lumpur, Malaysia.

Bell, D. (1997), Technical Advice Note 8: The Historic Scotland Guide to International Charters, HMSO, Edinburgh.

Blessing, O., Richard, J. and Emmanuel, A. (2015), Assessment of building maintenance management practices of higher education institutions in Niger State - Nigeria, Journal Of Design And Built Environment, 15(2).

Crishna, N., Banfill, P. F. G. and Goodsir, S. (2011), Embodied energy and CO2 in UK dimension stone. Resources, Conservation and Recycling, 55(12); 265-1273, doi: 10.1016/j.resconrec.2011.06.014.

Department of Environment, Food and Rural Affairs (DEFRA)/Department of Energy and Climate Change (DECC). (2009) Guidelines to Defra/DECC's GHG Conversion Factors for Company Reporting, Defra/DECC, London and Edinburgh.

Dore, S., Gratreak, L. and Phillips, A. (2013), Brick in Masonry Conservation Handbook. Architecture and Allied Arts, University of Oregon. USA.

Durnan, N. and Muir, C. (2006), Principles and Practice In Henry, A. (Ed), Stone Conservation; Principles and Practice (1 ed), Routledge, USA. pp 75-88.

English Heritage (2007), Conservation Principles, Policies and Guidance for the Sustainable Management of the Historic Environment, (Second Stage Consultation), English Heritage, London, UK.
Fielden, B.M. and Jokilehto, J. (1993), Management Guideliness for World Cultural Heritage Sites, ICCROM, Rome.

Forster A.M, and Carter, K. (2011), A framework for specifying lime mortars for rubble masonry construction. Structural Survey, Journal of Building Pathology and Refurbishment, 29(5); 373-396, doi:10.1108/02630801111182411

Forster, A. M., Carter, K., Banfill, P. F. G. and Kayan, B. A. (2011), Green maintenance For Historic Masonry Buildings: An Emerging Concept, Building Research \& Information, 39(6); 654-664. doi: 10.1080/09613218.2011.621345

Forster, A.M. (2010), Building conservation philosophy for masonry repair: Part 2. 'Principles', Structural Survey, 28 (3): 165188.

Forster, A.M. and Kayan, B. A. (2009), Maintenance for historic buildings: a current perspective, Structural Survey, Vol. 27 Iss: $3 ; 210-229$.

Forster, A.M., Carter, K., and Kayan, B. (2013), Greening Maintenance. RICS Building Conservation Journal, December 2013/January 2014: 32-33.

Forsyth, M. (2007), Understanding historic building conservation. Oxford, Blackwell.

Foulks, W. (1997), Historic Building Façades: the manual for maintenance and rehabilitation, New York, John Wiley.

Giesekam, J. Barret, J.R. and Taylor, P. (2016), Construction sector views on low carbon building materials, Building. Res. Inf. 44 (4); 423-444

Guinée, J.B. (2002), Handbook on Life Cycle Assessment: Operational Guide to the ISO Standards, Kluwer Academic Publisher, Dordrecht.

Hammond G.P., and Jones, C.I. (2011), Inventory of Carbon and Energy (ICE), Beta Version V2.0, Department of Mechanical Engineering, University of Bath, 2011 (available at: http:// www.bath.ac.uk/mecheng/sert/embodied/) (accessed 20 July 2016).

$\mathrm{Hu}$ Y.L. and Wang J. (2016), Analysis on the case of green reconstruction of the existing buildings, Chemical Engineering Transactions (51): 841-846.

$\mathrm{Hu}$, J.L. and Wang, S.C. (2006), Total-factor energy efficiency of regions in China, Energy Policy, 34 (17): 3206-3217.

Hyslop, E. (2006). Sourcing and Selection of Stone for Repair In Henry, A. (Ed), Stone Conservation; Principles and Practice, Routledge, USA. pp 89-100.

Hyslop, E. (2004), The Performance of 
Replacement Sandstone in the New Town of Edinburgh, Research Report. Historic Scotland, Edinburgh.

Ibrahim, W.Z.W. (2007), Towards a Sustainable Quarry Industry in Malaysia. Jurutera, (December): 22-25.

Jabatan Warisan Negara (JWN). (2008), Laporan Kerja-Kerja Konservasi dan Mendirikan Semula Kota Tembok Melaka Sektor 1 (Bastion Middelburg), Jalan Quayside, Melaka, Melaka: Jabatan Warisan Negara, Malaysia.

Kayan, B.A., Halim I.A., and Mahmud, N.S. (2018), Green Maintenance for heritage buildings: low carbon laterite stones repair appraisal Chemical Engineering Transactions, 63, 61-66 DOI:10.3303/CET183011

Kayan, B.A., Halim I.A., and Mahmud N.S. (2017), Green maintenance for heritage buildings: low carbon repair appraisal approach on laterite stones, Chemical Engineering Transactions, 56, 337-342 DOI:10.3303/CET1756057.

Kayan, B. A (2006), Building maintenance in old building conservation approach: an overview of related problems, Journal of Design and the Built Environment, 2 (2); 41-56.

Kayan, B.A. (2013), Green Maintenance for Historic Masonry Buildings: A Life Cycle Assessment Approach, Ph.D. Thesis, HeriotWatt University, Edinburgh, Scotland, United Kingdom

Kayan, B.A. (2017), Green maintenance for heritage buildings: paint repair appraisal, International Journal of Building Pathology and Adaptation, 35 (1); 1-29, doi: 10.1108/IJBPA-05-2016-0011

Khoo, T.T. (1998), Coral as Building Material in Late Portuguese and Early Dutch Malacca, Journal of the Malaysian Branch of the Royal Asiatic Society, 70, 2 (273); 97-114.

Knight, A. and Ruddock, L. (2008), Advanced Research Methods in the Built Environment, West Sussex, UK, Wiley-Blackwell.

Lavagna, M. (2012), The role of the functional equivalence in LCA of buildings and building products. Proceedings of the International Symposium on Life Cycle Assessment and Construction, Nantes, France.

Levine, M., Urge-Vorsatz, D., Blok, K., Geng, L., Harvey, D., Lang, S., . . . Yoshino, H. (2007). Residential and commercial buildings. In B. Metz, O. R. Davidson, P. R. Bosch, R. Dave \& L. A. Meyers (Eds.), Contribution of working group iii to the fourth assessment report of the intergovernmental panel on climate change. Cambridge: Cambridge University Press, Cambridge, United Kingdom.

Lime Mortar Suppliers \& Stone Restoration Specialists. (2016), Lime Plaster Calculator (available at: http://www.limemortars.co.uk/calculators/plaster) (accessed 29 July 2017).

Lime Mortar Suppliers \& Stone Restoration Specialists. (2016), Mortar Calculator (available at: http://www.limemortars.co.uk/calculators/mortar) (accessed 20 July 2017).

Loron, M. S., Ismail, S. and Yumos, M. M. Y. (2015), Energy Efficiency for Reducing Carbon Footprint in Historic Buildings: Comparing Case in the UK and Malaysia, Advances in Environmental Biology, 9(4); 82-84.

Luiza, F. L. Sarayed-Din, L.F., Zainol, R. and Ahmad, F. (2017), The Role of History In Informality In The Global South City Of Kuala Lumpur: The Case Of Kampong Bharu Development, Journal of Surveying, Construction and Property (JSCP), 8 (1); 1 10.

Matias, G., Torres, I. and Faria, P (2016), Air Lime and Natural Hydraulic Lime mortars with Ceramic Residues for Rehabilitation of Old Buildings Proceedings of the $41^{\text {st }}$ IAHS WORLD CONGRESS, Sustainability and Innovation for the Future, Albufeira, Algarve, Portugal.

Ministry of Natural Resources and Environment Malaysia (2015), Malaysia Biennial Update Report to the UNFCC; Putrajaya Malaysia

Moncaster, A. (2015), Pathways to Low Carbon Building: Reflection on the Special Issue. Buildings, 5:751-758

Mustafa, N. A. and Abdullah, N.C. (2013), Preservation of Cultural Heritage in Malaysia: An Insight of The National Heritage Act 2005, Proceedings of International Conference on Tourism Development (ICTD), G Hotel, Pulau Pinang.

Pendleton, R. (1941), Laterite and Its Structural Uses in Thailand and Cambodia, Geographical Review, 31 (2);177-202.

Pendleton, R. (1952), Laterite and lateritic soils, Commonwealth Bureau of Soil Science, Tech. Comm., Report No. 47.

Perkins, N. D. (2008), Livability, Regional Equity, and Capability: Closing in on Sustainable Land Use, University of Baltimore Law Review, 37. pp 157-202.

Rahim, M. F. A., Muzafar, S., Zakaria, N., Zainon, N., and Johari, P. (2016), 
Implementation of Life Cycle Costing in Enhancing Value for Money of Projects. International Journal Of Property Sciences (E-ISSN: 2229-8568), 6(1). (available at: https://ejournal.um.edu.my/index.php/IJPS/a rticle/view/4127) (accessed 4 December 2017).

Ramli, M. and Byrd, H. (2012), Towards a sustainable built environment in Malaysia, Penerbit Universiti Sains Malaysia EPUB, 2015, Universiti Sains Malaysia, USM Pulau Pinang, Malaysia.

Rawlinson, S. and Weight, D. (2007), Sustainability Embodied Carbon, (available at:

http://www.building.co.uk/data/sustainabilit $\mathrm{y}-$

\%E2\%80\%94embodiedcarbon/3097160.arti cle) (accessed 13 July 2017)

Tan, K. (2015), Mission Pioneers of Malaya. School of Architecture, Building and Design, Taylor's University. Subang Jaya, Malaysia.

Torney, C., Forster, A. M. Szadurski, Hyslops, E. (2014), Specialist 'restoration mortars' for stone elements: a comparison of the physical properties of two stone repair materials. Heritage Science, 2(1); 1. doi: 10.1186/2050-7445-2-1

United Nations Educational, Scientific and Cultural Organization (2013), New Life for Historic Cities, The Historic Urban Landscape Approach Explained, UNESCO France 